\title{
Light and temperature acclimation of Rhodomonas salina (Cryptophyceae): photosynthetic performance
}

\author{
Astrid Hammer ${ }^{1, *}$, Rhena Schumann ${ }^{1}$, Hendrik Schubert ${ }^{2}$ \\ ${ }^{1}$ University of Rostock, Department of Life Sciences, Institute of Aquatic Ecology, Albert-Einstein-Str. 3, 18051 Rostock, Germany \\ ${ }^{2}$ University of Greifswald, Institute of Ecology, Grimmer Str. 88, 17487 Greifswald, Germany
}

\begin{abstract}
Blooms of phototrophic cryptophytes have been observed in the highly eutrophic estuarine Darss-Zingst Bodden Chain (DZBC), Germany, during prolonged periods of light limitation due to ice and snow covering. The present study analyses possible mechanisms by which Rhodomonas salina, as a surrogate for bloom forming DZBC cryptophytes, maintains large densities during these low light/low temperature conditions. Growth, photosynthetic activity and pigment content were examined under 16 combinations of temperature $\left(5\right.$ to $\left.20^{\circ} \mathrm{C}\right)$ and irradiance $\left(10\right.$ to $150 \mu \mathrm{mol}$ photons $\left.\mathrm{m}^{-2} \mathrm{~s}^{-1}\right)$ under nutrient-saturated conditions in a seawater-based medium. $R$. salina was tested for its capacity to photoacclimate to different light intensities in relation to temperature by calculating the photoadaptive index $E_{\mathrm{k}}$ (light saturation point of photosynthesis, $P_{\max } / \alpha$ ). $P_{\max }$ the maximum photosynthesis rate and $\alpha$, the efficiency of light utilisation at limited light intensities remained unchanged with respect to irradiance for every temperature tested. Consequently $E_{\mathrm{k}}$, the irradiance at which photosynthesis rate ceased to be light-limited was constant (mean $49 \mu \mathrm{mol}$ photons $\mathrm{m}^{-2} \mathrm{~s}^{-1}$ ) within the chosen range of irradiances. This indicated that $R$. salina failed to adapt to down-shift changes in the light regime, at least in terms of photosynthetic parameters. Pigmentation analyses supported these results showing no acclimation of pigment ratios with regard to growth irradiance for a particular temperature. The calculated irradiance needed for 0 net photosynthesis $\left(E_{\mathrm{c}}\right)$ was about $26 \mu$ mol photons $\mathrm{m}^{-2} \mathrm{~s}^{-1}$ and did not show any significant variation in light or temperature. The failure of $R$. salina to respond to down-shift changes in the light regime did not result, however, in a reduction in growth at low irradiances $\left(10 \mu \mathrm{mol}\right.$ photons $\left.\mathrm{m}^{-2} \mathrm{~s}^{-1}\right)$. Judging from these results, $R$. salina seems to pursue an alternative strategy to capture energy under low light conditions which we hypothesise to be uptake of dissolved organic carbon from the seawater-based medium. Follow-up research will concentrate on the relative contribution of heterotrophy to the overall nutrition of $R$. salina under white ice covering.
\end{abstract}

KEY WORDS: Bloom $\cdot$ Cryptophytes $\cdot$ Rhodomonas salina $\cdot$ Ice $\cdot$ Photosynthesis $\cdot$ Photoacclimation Resale or republication not permitted without written consent of the publisher

\section{INTRODUCTION}

Several occurrences of cryptophyte blooms have been reported for a broad spectrum of lake types and nutrient regimes, suggesting that these organisms contribute substantially to planktonic metabolic processes (reviewed in Stewart \& Wetzel 1986, Klaveness 1989, Gervais 1997). Cryptophytes often arise during winter in ice-covered lakes (Stewart \& Wetzel 1986). Most winter studies are performed in lakes located in polar

*E-mail: astrid.hammer@stud.uni-rostock.de and subpolar regions (e.g. Vincent 1981, Roberts \& Laybourn-Parry 1999, McKnight et al. 2000) or in high mountain lakes (e.g. Rott 1988, Felip et al. 1999) of oligo- to mesotrophic character. Less information exists about blooms in shallow eutrophic to hypertrophic lakes of the temperate climate zone (reviewed in Nebaeus 1984, Wiedner \& Nixdorf 1998) or eutrophic coastal areas (Bothnian Bay in the Baltic Sea, Ikävalko 1997). The Darss-Zingst Bodden Chain (DZBC), situated at the southern coastline of the Baltic Sea, is one such eutrophic to hypertrophic shallow water estuarine system. Small cryptophytes can reach extremely high abundances during periods of persistent ice cover

(C) Inter-Research $2002 \cdot$ www.int-res.com 
(Wasmund 1994, Schumann unpubl. data). Whereas in arctic regions, low-light stress is caused by low annual doses of photosynthetic active radiation (e.g. LaybournParry et al. 1996), in the DZBC high eutrophication results in light limitation of primary production (Schiewer 1997). High amounts of particulate and dissolved organic carbon (DOC) have a significant effect of underwater irradiance distribution in the DZBC (Schubert et al. 2001). Regular periods of ice and snow covering are a further stressful event. Ice covering lasts for up to 3 mo and opaque ice with snow covering plus sea ice crystals and particulate material result in almost total darkness below ice (Schubert et al. 2001).

Following Rodhe's (1955) question: 'Can plankton production proceed during winter darkness in subarctic lakes?' various hypotheses have been suggested to explain the winter survival of cryptophytes. The most commonly cited reasons are: (1) decreased predation pressure on cryptophytes (review in Stewart \& Wetzel 1986); (2) extreme low-light adaptation, obtained by large and effective light harvesting complexes (phycobiliproteins) (Palmisano et al. 1985, Arrigo et al. 1993, Robinson et al. 1995); and (3) low metabolic rates (e.g. Cryptomonas erosa, Morgan \& Kalff 1975) enabling long survival periods of these organisms. A controversial point in dark survival of cryptophytes is the importance of mixotrophy (Salonen \& Jokinen 1988, Sanders et al. 1989, Tranvik et al. 1989, Gasol et al. 1993, Gervais 1997).

When light availability is the major factor controlling growth of ice algae (Marra \& Boarman 1984, Sakshaug \& Holm-Hansen 1986), phototrophic organisms should respond to variations in the light climate by photoadaptive processes. Several studies (e.g. Haxo \& Fork 1959, Wright 1964, Morgan \& Kalff 1975) have shown that cryptophytes are able to adapt to low mean irradiance by increasing the amount of light harvesting pigments. In contrast, Post et al. (1984) argued that these flagellates may depend more on motility than on photoadaptional capacity to obtain optimal light intensity. Whereas morphology (e.g. Santore 1977, Klaveness 1981), pigmentation (e.g. MacColl et al. 1976, Thinh 1983), as well as systematics and phylogeny (Klaveness 1985) have been extensively studied, a photosynthetic characterisation of Cryptophyceae exists only for very few species (Cryptomonas lis, Thinh 1983, 1988; C. obavata, Giroldo \& Vieira 1999). To our knowledge $E_{\mathrm{k}}$, a useful index of acclimation to different light conditions (Talling 1957, Henley \& Ramus 1989), has been calculated only for C. lis (Thinh 1983, 1988). Therefore, information on cryptophyte photoacclimation kinetics is needed to clarify whether or not special features in light utilisation capabilities are responsible for the observed winter dominance of cryptophytes. Moreover, ecophysiological studies (in situ and in vivo) of growth kinetics are still scarce for Cryptophyceae (Cloern 1977, Ojala 1993a).

In this article, we assess the complex effect of various combinations of light and temperature on photosynthesis and growth rates of Rhodomonas salina, used as a surrogate for DZBC bloom cryptophytes, under nutrient-saturated conditions. Of particular interest were the effects of irradiance and temperature on modulation of photosynthetic efficiency, which is thought to be the most important acclimation mechanism of autotrophic individuals (Henley \& Ramus 1989).

\section{MATERIALS AND METHODS}

Experimental design. We followed changes in growth, pigment content and photosynthetic activity of the cryptophyte alga Rhodomonas salina at varying light and temperature conditions. Cultures acclimated to the appropriate conditions were grown under combinations of 4 quantum irradiances from 10 to $150 \mu \mathrm{mol}$ photons $\mathrm{m}^{-2} \mathrm{~s}^{-1}$ and 4 temperatures from 5 to $20^{\circ} \mathrm{C}$. Samples were taken daily for growth rate determination. Biovolume, pigmentation and photosynthetic parameters were measured in the mid-exponential growth phase, which, depending on the light/temperature regime, occurred between Days 6 and 15. For each treatment, we determined the exact time of the mid-exponential growth phase in pre-experiments, adjusting our main experiments accordingly. Experiments were replicated by using 2 to 3 concurrently grown batches of cultures.

Organism and culture conditions. The cryptophyte Rhodomonas salina (Wislouch) Hill and Wetherbee (Cryptophyceae) (978/24) was obtained from the Culture Collection of Algae and Protozoa (CCAP) and originates from a brackish, eutrophic and lower latitude water body comparable to DZBC.

Cultures were maintained in $\mathrm{f} / 2$ medium, a seawater-based medium enriched with nitrate $(742 \mu \mathrm{M})$, phosphate $(36.2 \mu \mathrm{M})$, vitamins and trace metals to maintain nutrient-saturated growth. Medium salinity was $6.8 \mathrm{psu}$ and the $\mathrm{pH}$ was 8.0, with both values lying well within the ranges of 2 to $13.2 \mathrm{psu}$ and $\mathrm{pH} 7.4$ to 9.5, for which Wasmund (1994) established cryptophyte occurrence in the DZBC (maximum occurrence at 8.3 psu and $\mathrm{pH} 8.4$ ).

Cultures used for inocula were allowed to acclimate to the appropriate conditions by 2 repeated transfers of cells in the mid-exponential growth phase (Days 6 to 15 depending on treatment, see above) into fresh sterile medium. At the beginning of the experiments, these pre-acclimated cultures were diluted with sterile medium to a cell density of approximately $2 \times 10^{5} \mathrm{ml}^{-1}$.

Experimental batch cultures were grown under aeration in $150 \mathrm{ml}$ carboys (Duran glass), thermostated at 5, 
10,15 and $20^{\circ} \mathrm{C}$ under a $12: 12 \mathrm{~h}$ light:dark cycle. These incubation temperatures were within the range of 0.1 to $21.4^{\circ} \mathrm{C}$, for which Wasmund (1994) established cryptophyte occurrence in the DZBC. The daily courses of underwater light in the DZBC for the time of cryptophyte blooms (November to February) were calculated from simulated surface light courses after correction for reflection according to Walsby (1997). In ice-free winters, daily light doses were approximately $6.54 \mathrm{~mol} \mathrm{~m}^{-2}$ between November and February, corresponding to the maximum value of $150 \mu \mathrm{mol}$ photons $\mathrm{m}^{-2} \mathrm{~s}^{-1}(=6.48 \mathrm{~mol}$ $\mathrm{m}^{-2}$ ) that we chose for the experimental $12: 12 \mathrm{~h}$ cycle. In the DZBC, a maximum of $0.43 \mathrm{~mol} \mathrm{~m}^{-2} \mathrm{~d}^{-1}$ reaches the cryptophytes under white ice covering, which corresponds to the experimental $10 \mu \mathrm{mol}$ photons $\mathrm{m}^{-2} \mathrm{~s}^{-1}$. Irradiation at 10, 30, 60 and $150 \mu \mathrm{mol}$ photons $\mathrm{m}^{-2} \mathrm{~s}^{-1}$ (growth irradiation, $E_{\mathrm{g}}$ ) was obtained by combining 5 cool white fluorescent tubes (Radium NL 36W/25) with neutral density filters. Irradiance was measured inside the culture glass vessels using a spectroradiometer (Macam SR9901, Macam) equipped with a $4 \pi$-spherical underwater sensor.

Biovolume, growth rates, pigments and primary production. Daily cell counts of living flagellates and volume determinations of $1 \%$ ice-cooled glutaraldehyde preserved samples were made by microscopic examination within $3 \mathrm{~d}$ after fixation, using a Bürker counting chamber. Average cell volume was determined from the size of at least 50 cells, according to the equation for spheroids given in Tranvik et al. (1989).

Growth rates were calculated from the equation $\mu=$ $\left(\mathrm{ln}_{\mathrm{N} 2}-\ln _{\mathrm{N} 1}\right) /\left(t_{2}-t_{1}\right)$, where $\mathrm{N} 1$ and $\mathrm{N} 2$ are the average values of cell numbers at times $t_{1}$ and $t_{2}$, corresponding to the beginning and the end, respectively, of exponential growth. We used GraphPad Prism 2.0 (GraphPad Software) to determine the beginning and end of the exponential growth.

For chlorophyll a (chl a) determination, duplicate subsamples of 5 to $10 \mathrm{ml}$ of the algal suspension, filtered onto a Whatman GF/F filter, were extracted in $3 \mathrm{ml}$ of DMF ( $N, N$-dimethylformamide) and stored in darkness at $4^{\circ} \mathrm{C}$ for ca. $5 \mathrm{~h}$. Absorption was measured with an UV/VIS spectrophotometer (Lambda 2, Perkin Elmer). Pigment contents $\left(\mu \mathrm{g} \mathrm{ml}{ }^{-1}\right)$ were calculated from the absorbance spectra of the extracts according to Porra et al. (1989). Phycoerythrin (PE) content was determined spectrophotometrically as described in Sciandra et al. (2000).

Measurements of the photosynthesis-irradiance ( $P$ $E$ ) curves were performed for 14 out of the 16 lighttemperature treatments as well as for their replicates. $\mathrm{Chl}$ a contents were insufficient to allow oxygen electrode measurements of the irradiance-temperature regimes $60 / 150 \mu \mathrm{mol}$ photons $\mathrm{m}^{-2} \mathrm{~s}^{-1}$ and $5^{\circ} \mathrm{C}$. To avoid variability due to possible fluctuation of photosynthe- sis, experiments were always carried out $2 \mathrm{~h}$ after the start of a light phase. Net oxygen exchange rates, at 9 increasing light intensities from 0 to approximately $1100 \mu \mathrm{mol}$ photons $\mathrm{m}^{-2} \mathrm{~s}^{-1}$, were measured with a Clarke type oxygen electrode using a computer controlled Light Dispensation System (MK2, ILLUMINOVA, described in Wolfstein \& Hartig 1998). One measurement of a $P$ - $E$ curve took about $40 \mathrm{~min}$. After an equilibration time of 10 min darkness, measurement started with 10 min darkness, followed by a stepwise, successive increase of irradiance. Each irradiance step lasted for $4 \mathrm{~min}$. Temperature was set according to the respective acclimation temperature. Photosynthetic parameters were derived by a fitting procedure applied to each individual sample. Because photoinhibition was not evident, we used an iterative exponential regression with the 2-parameter equation of Webb et al. (1974):

$$
P=P_{\max }\left(1-\mathrm{e}^{\alpha E / P_{\max }}\right)+R
$$

where $P$ is the photosynthesis rate at irradiance $E, P_{\max }$ is the maximum photosynthesis rate obtained at saturating irradiance in the absence of photoinhibition, $R$ is the rate of respiration and $\alpha$ the initial slope of the $P-E$ curve (light dependency of photosynthesis at limited irradiances). $P_{\mathrm{i}}$, the photosynthesis rate at growth irradiance $E_{\mathrm{g}}$, was calculated according to the respective fitted equation. $E_{\mathrm{k}}$ (light saturation point and index of light adaptation, $P_{\max } / \alpha$, Talling 1957) and $E_{\mathrm{c}}$ (compensation irradiance at which respiratory oxygen demand is balanced by photosynthesis) were determined according to Platt et al. (1980).

Statistics. All analyses were conducted using GraphPad Prism 2.0 (GraphPad Software). After $\log _{10}$-transformation in order to stabilise the variances, 2-way ANOVAs were performed to test for differences between light and temperature exposure history with respect to growth rate, pigments and photosynthetic parameters. Post tests were applied to test for linear trends and to identify groups differing from the others if there was a significant difference $(p<0.05)$ for the respective parameters (Tukey's test). 3D graphics were derived by a surface fitting procedure using simple polynomial equations (TableCurve 3D, AISN software). Equations are given in the legends with $\mathrm{r}^{2}$, standard error and $F$-value.

\section{RESULTS}

\section{Growth}

Thirteen out of the 16 light-temperature combinations resulted in significant growth. Three combinations, $T=$ $5^{\circ} \mathrm{C}, E_{\mathrm{g}}=30,60$ and $150 \mu \mathrm{mol}$ photons $\mathrm{m}^{-2} \mathrm{~s}^{-1}$, did not 


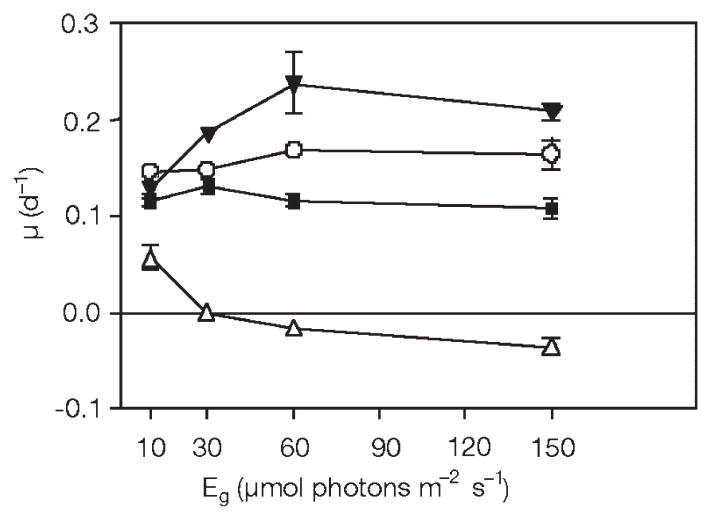

Fig. 1. Rhodomonas salina. Growth rates $(\mu)$ at different incubation irradiances $\left(E_{\mathrm{g}}\right)$ and temperatures. Error bars $= \pm \mathrm{SD}$. $(\Delta) 5^{\circ} \mathrm{C},(\square) 10^{\circ} \mathrm{C},(\mathrm{O}) 15^{\circ} \mathrm{C},(\nabla) 20^{\circ} \mathrm{C}$

support growth (Fig. 1). The growth rate of Rhodomonas salina showed only small irradiancedependent changes $(10 \%$ of variances explained by irradiance; $p>0.05,2$-way ANOVA). This is most marked at 10 and $15^{\circ} \mathrm{C}$ with almost constant growth rates of 0.11 to $0.13 \mathrm{~d}^{-1}$ and 0.15 to $0.17 \mathrm{~d}^{-1}$, respectively, within the range of growth irradiances. The irradiance for maximum growth slightly decreased ( $\mathrm{p}>0.05$ ) with decreasing temperature; at $20^{\circ} \mathrm{C}$, it was $60 \mu \mathrm{mol} \mathrm{m} \mathrm{m}^{-2} \mathrm{~s}^{-1}$ and at $5^{\circ} \mathrm{C}$, it dropped to $10 \mu \mathrm{mol} \mathrm{m} \mathrm{m}^{-2} \mathrm{~s}^{-1}$. Photoinhibition of growth could be observed in the low temperature cultures above $10 \mu \mathrm{mol}$ photons $\mathrm{m}^{-2} \mathrm{~s}^{-1}$. Temperature explained $>70 \%$ of the variances in growth rate $(p<0.001,2$ way ANOVA), where growth increased significantly with increasing temperature $\left(\mathrm{r}^{2}=0.62, \mathrm{p}<0.001\right.$, post test for linear trend) and reached its maximum at $20^{\circ} \mathrm{C}$, the highest temperature examined $\left(0.24 \mathrm{~d}^{-1}\right.$ at $60 \mu \mathrm{mol} \mathrm{m} \mathrm{m}^{-2} \mathrm{~s}^{-1}$ ).

\section{Biovolume}

Similar to the growth rate, the cell size of Rhodomonas salina (mean $182 \mu^{3}$ ) was only slightly affected by irradiance $(17 \%$ of variance explained; $\mathrm{p}<0.01$, 2-way ANOVA), showing an insignificant decrease with increasing irradiance ( $p>0.05$; Fig. 2), whereas temperature accounted for $78 \%$ of the variances ( $p<0.001)$. The mean cell volume decreased significantly with increasing temperature $\left(\mathrm{r}^{2}=0.73, \mathrm{p}<0.01\right)$ at each level of irradiance. The smallest cells had an average volume of $110 \mu^{3}\left(T=20^{\circ} \mathrm{C}, E_{\mathrm{g}}=150 \mu \mathrm{mol} \mathrm{m}{ }^{-2}\right.$ $\left.\mathrm{s}^{-1}\right)$ and the largest of $341 \mu^{3}\left(T=5^{\circ} \mathrm{C}, E_{\mathrm{g}}=\right.$ $10 \mu \mathrm{mol}$ photons $\mathrm{m}^{-2} \mathrm{~s}^{-1}$ ) implying an up to 3 fold size difference within this strain.

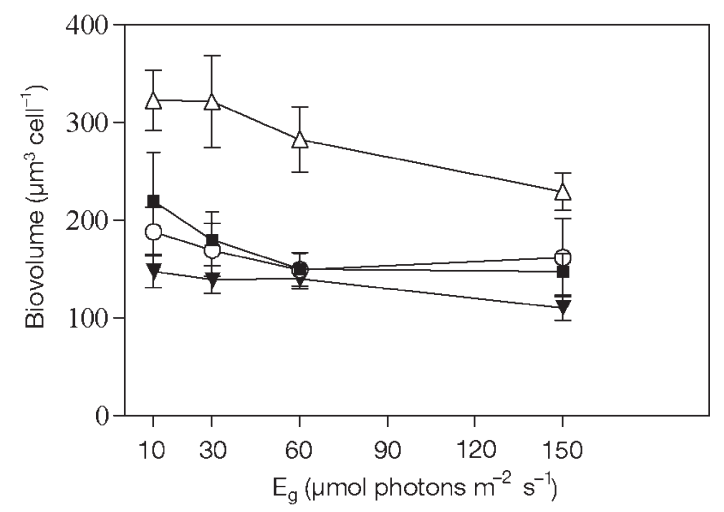

Fig. 2. Rhodomonas salina. Biovolume per cell at different incubation irradiances $\left(E_{\mathrm{g}}\right)$ and temperatures. Error bars $=$ $\pm \mathrm{SD} .(\Delta) 5^{\circ} \mathrm{C},(\mathbf{\square}) 10^{\circ} \mathrm{C},(\mathrm{O}) 15^{\circ} \mathrm{C},(\boldsymbol{\nabla}) 20^{\circ} \mathrm{C}$

\section{Pigmentation}

Cellular chl a content increased for all temperature regimes when irradiance dropped below $30 \mu \mathrm{mol}$ photons $\mathrm{m}^{-2} \mathrm{~s}^{-1}$ (Fig. 3). Chl a contents at $10 \mu \mathrm{mol}$ photons $\mathrm{m}^{-2} \mathrm{~s}^{-1}$ were significantly different from all other irradiance treatments for all temperature regimes $(\mathrm{p}<$ 0.01 , Tukey's test). This increase was approximately 4 fold in the high temperature cultures and 2-fold in the low temperature cultures. A significant positive effect of temperature on chl a content per cell $\left(\mathrm{r}^{2}=0.99, \mathrm{p}<\right.$ 0.01) was observed for the low-light culture $(10 \mu \mathrm{mol}$ photons $\mathrm{m}^{-2} \mathrm{~s}^{-1}$ ), whereas cultures grown at higher irradiances exhibited insignificant changes in cellular chl a with temperature $(\mathrm{p}>0.05)$.

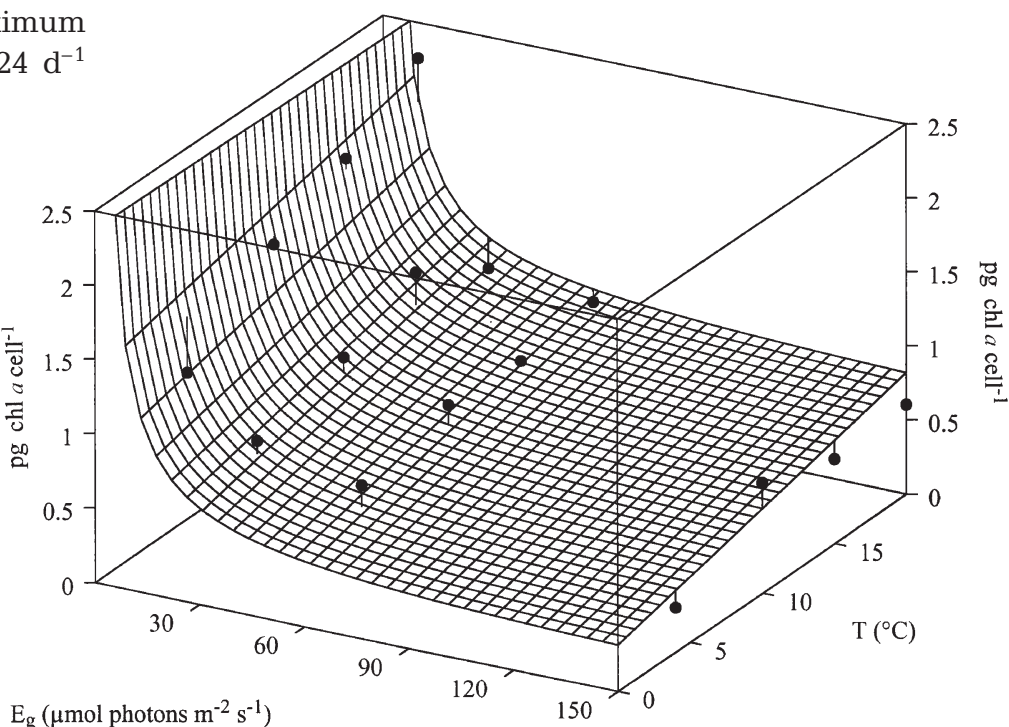

Fig. 3. Rhodomonas salina. Chl a per cell versus growth irradiance $\left(E_{\mathrm{g}}\right)$ and temperature $(T)$ relationship (mean value, $\mathrm{n}=3$ ). Fitted by the equation $z=$ $0.23+12.35 / x+0.03 y, r^{2}=0.88, \mathrm{SE}=0.20, F=47.13$. Error bars $= \pm \mathrm{SD}$ 
The PE/chl a ratio (Fig. 4) showed only small irradiance-dependent changes $(21 \%$ of variances explained, $\mathrm{p}<0.01$ ), reflecting that for a given temperature both cellular chl $a$ and PE (mean of 3.87 pg cell $^{-1}$ ) content depend on irradiance in the same way. The negative effect of temperature on PE is more pronounced than on chl $a$, resulting in a sharp decline in $\mathrm{PE} / \mathrm{chl}$ a with decreasing temperature $(73 \%$ of variances explained, $\left.r^{2}=0.71, p<0.001\right)$.

\section{Photosynthetic parameters}

In all $P$ versus $E$ curves, the maximum photosynthetic rate $\left(P_{\max }\right)$ was reached at $\geq 60 \mu \mathrm{mol}$ photons $\mathrm{m}^{-2} \mathrm{~s}^{-1}$, followed by a plateau without any signs of photoinhibition (single $P$-E curves not shown). Maximum photosynthetic rates varied for the entire data set between 78 and $146 \mathrm{mmol} \mathrm{O}_{2} \mathrm{~g} \mathrm{chl}$ $a^{-1} \mathrm{~h}^{-1}$ (mean of $96 \mathrm{mmol} \mathrm{O}_{2} \mathrm{~g} \mathrm{chl} a^{-1} \mathrm{~h}^{-1}$; Table 1). However, no significant variability with irradiance could be found within each temperature regime $(p>0.05)$. $P_{\max }$ increased significantly $(\mathrm{p}<$ 0.01 , Tukey's test) from 15 to $20^{\circ} \mathrm{C}$. The photosynthetic energy conversion efficiency, $\alpha$, did not vary signifi-

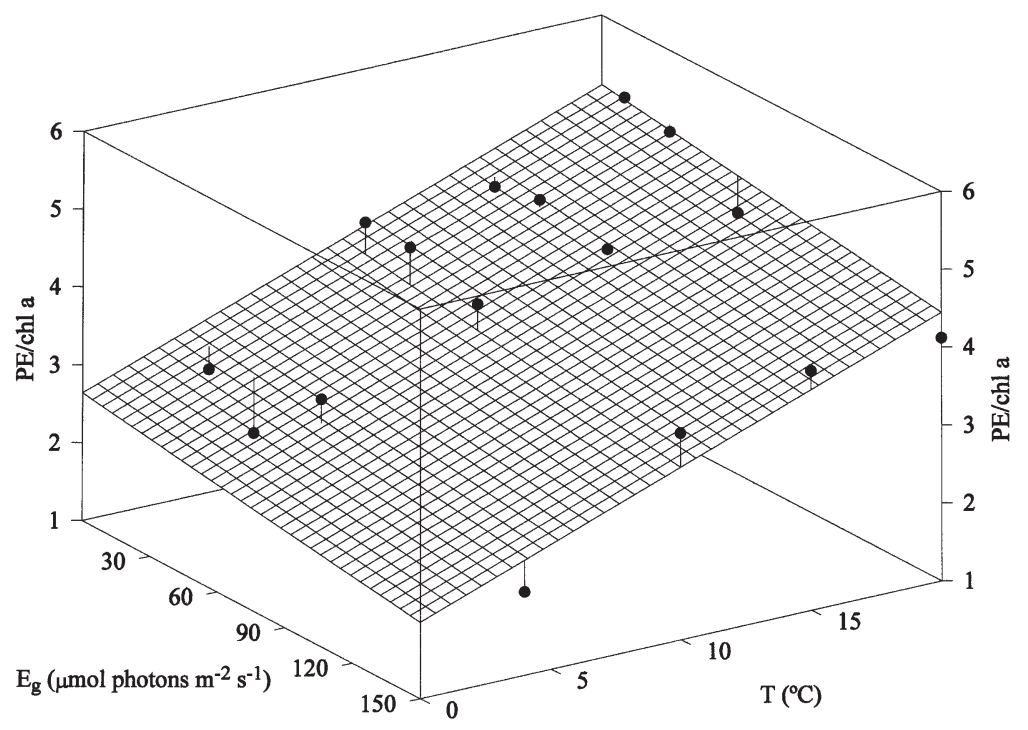

Fig. 4. Rhodomonas salina. Phycoerythrin (PE)/chl a per cell versus growth irradiance $\left(E_{\mathrm{g}}\right)$ and temperature $(T)$ relationship. Fitted by the equation $z=$ $2.64-0.004 x+0.12 y, r^{2}=0.79, \mathrm{SE}=0.04, F=24.70$. Error bars $= \pm \mathrm{SD}$

Table 1. Photosynthetic characteristics of Rhodomonas salina cultured in different growth irradiance $\left(E_{\mathrm{g}}\right)$; temperature $(T)$ regimes: maximum gross photosynthesis per chl a $\left(P_{\max \cdot c h l} a\right)$, initial slope per chl $a\left(\alpha_{\mathrm{chl}}\right)$ of the $P$ - $E$ curve, light saturation constant $\left(E_{\mathrm{k}}\right)$, gross photosynthetic performance $\left(P_{\mathrm{i}}\right)$ and dark respiration $(R)$ per chl $a$ and per cell, and compensation irradiance of photosynthesis $\left(E_{\mathrm{c}}\right)$. Means of $P_{\max }, P_{\mathrm{i}}$ and $R$ from exponentially growing cultures were calculated from triplicate cultures. Coefficient of variation ranged from 5 to $10 \%$. Chl a contents were insufficient to allow oxygen electrode measurements of the irradiance-temperature regimes $60 / 150 \mu \mathrm{mol}$ photons $\mathrm{m}^{-2} \mathrm{~s}^{-1}$ and $5^{\circ} \mathrm{C}$

\begin{tabular}{|c|c|c|c|c|c|c|c|c|c|c|}
\hline$E_{g}$ & $T\left({ }^{\circ} \mathrm{C}\right)$ & $P_{\text {max }} \cdot \operatorname{chl~a}$ & $\alpha_{\mathrm{chl} a}$ & $E_{\mathrm{k}}$ & Gross $P_{\mathrm{i} \cdot \mathrm{chl} a}$ & Gross $P_{\mathrm{i} \cdot \text { cell }}$ & $R_{\mathrm{chl} \mathrm{a}}$ & $R_{\text {cell }}$ & $R / P_{\mathrm{i}}$ & $E_{\mathrm{c}}$ \\
\hline \multirow[t]{4}{*}{10} & 5 & 87.9 & 1.3 & 65 & 12.6 & 15.0 & 26.05 & 31.0 & 2.1 & 19 \\
\hline & 10 & 87.2 & 1.9 & 45 & 18.2 & 30.3 & 32.90 & 54.7 & 1.8 & 18 \\
\hline & 15 & 77.9 & 3.6 & 22 & 29.1 & 55.6 & 44.18 & 84.5 & 1.5 & 25 \\
\hline & 20 & 80.0 & 1.1 & 71 & 9.3 & 21.1 & 30.28 & 68.4 & 3.2 & 14 \\
\hline \multirow[t]{4}{*}{30} & 5 & 115.6 & 2.5 & 46 & 51.7 & 42.9 & 33.33 & 27.7 & 0.6 & 22 \\
\hline & 10 & 94.0 & 2.1 & 45 & 50.7 & 50.5 & 41.48 & 41.3 & 0.8 & 28 \\
\hline & 15 & 87.1 & 3.8 & 23 & 64.8 & 80.3 & 50.44 & 62.5 & 0.8 & 19 \\
\hline & 20 & 125.4 & 1.5 & 84 & 30.6 & 28.6 & 37.97 & 35.5 & 1.2 & 39 \\
\hline \multirow[t]{4}{*}{60} & 5 & - & - & - & - & - & - & - & - & \\
\hline & 10 & 89.5 & 2.0 & 44 & 63.4 & 52.0 & 45.25 & 37.1 & 0.7 & 39 \\
\hline & 15 & 82.4 & 4.1 & 20 & 81.6 & 64.0 & 47.92 & 37.6 & 0.6 & 17 \\
\hline & 20 & 102.3 & 2.8 & 37 & 79.8 & 68.0 & 51.04 & 43.5 & 0.6 & 25 \\
\hline \multirow[t]{4}{*}{150} & 5 & - & - & - & - & - & - & - & - & - \\
\hline & 10 & 83.1 & 1.8 & 47 & 73.9 & 54.4 & 45.41 & 33.4 & 0.6 & 27 \\
\hline & 15 & 91.2 & 2.6 & 35 & 92.5 & 52.3 & 49.41 & 28.0 & 0.5 & 27 \\
\hline & 20 & 146.7 & 1.9 & 77 & 100.8 & 60.5 & 64.12 & 38.5 & 0.6 & 55 \\
\hline \multicolumn{11}{|c|}{ 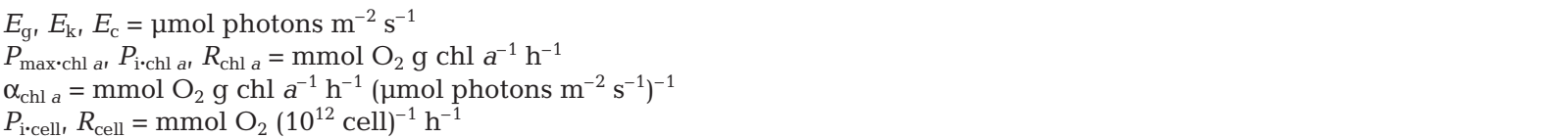 } \\
\hline
\end{tabular}




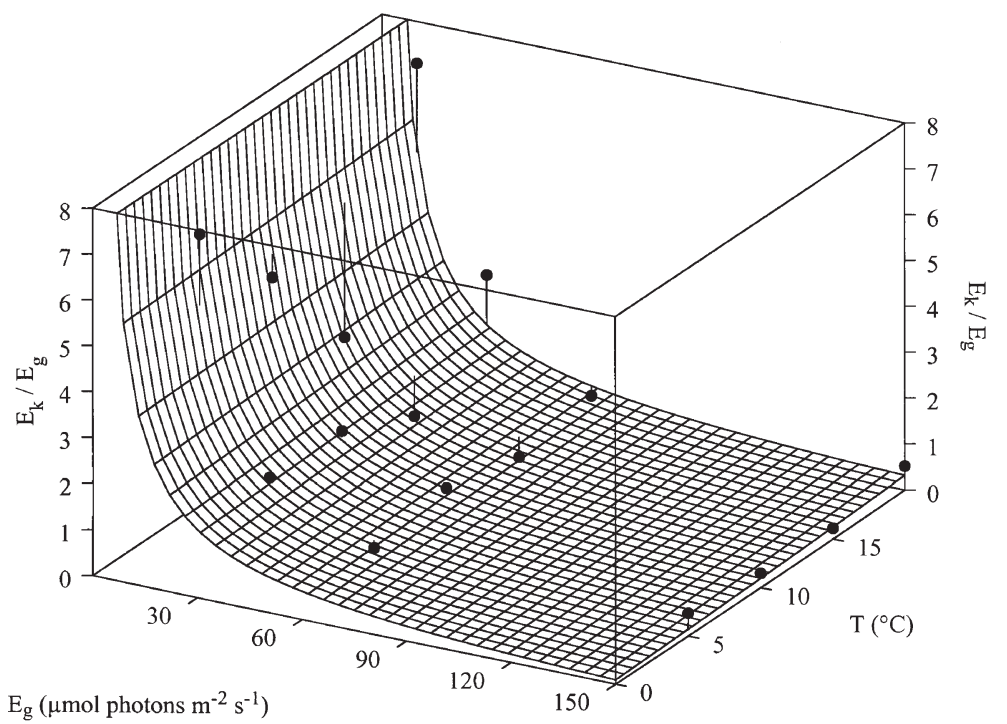

Fig. 5. Rhodomonas salina. $E_{\mathrm{k}} / E_{\mathrm{g}}$ versus growth irradiance $\left(E_{\mathrm{g}}\right)$ and temperature $(T)$ relationship. Fitted by the equation $z=-0.20+51.85 / x+0.01 y, r^{2}=$ $0.77, \mathrm{SE}=1.16, F=21.24$. Error bars $= \pm \mathrm{SD}$. A value of $E_{\mathrm{k}} / E_{\mathrm{g}}<1$ indicates light limitation

Tukey's test; Table 1). Consequently, the calculated light saturation constant, $E_{\mathrm{k}}\left(P_{\max } / \alpha\right)$, was relatively constant over the range of growth irradiances (mean of $47 \mu \mathrm{mol}$ photons $\mathrm{m}^{-2} \mathrm{~s}^{-1}$ ) for each temperature regime and was in all cases above the lowest examined growth irradiance $\left(10 \mu \mathrm{mol}\right.$ photons $\mathrm{m}^{-2} \mathrm{~s}^{-1}$; Table 1$)$. This is depicted in Fig. 5, where a value of $E_{\mathrm{k}} / E_{\mathrm{g}} \leq 1$ occurred only in cultures growing at $E_{\mathrm{g}} \geq 60 \mu \mathrm{mol}$ photons $\mathrm{m}^{-2} \mathrm{~s}^{-1}$, thus indicating light limitation below this level of irradiance. Regardless of $E_{\mathrm{g}}, E_{\mathrm{k}}$ was always lowest at $15^{\circ} \mathrm{C}$ (mean 25 umol $\mathrm{m}^{-2} \mathrm{~s}^{-1}$ ) (Table 1), which reflects the highest $\alpha$ at this temperature (Table 1 ).

\section{Respiration}

An approximately 2-fold increase in respiration rates normalised to $\mathrm{chl} a(\mathrm{p}<0.01)$ was observed over the examined range of growth irradiances/temperatures (Table 1). Respiration per cell was inversely related to irradiance because of decreases in cell chl a with growth irradiance (Fig. 3). The ratio of respiration to gross photosynthesis at the growth irradiance $E_{\mathrm{g}}\left(R / P_{\mathrm{i}}\right)$ decreased with increasing irradiance, and $\mathrm{P}_{\mathrm{i}}$ exceeded $R$ only for levels above approximately $30 \mu \mathrm{mol}$ photons $\mathrm{m}^{-2} \mathrm{~s}^{-1}$ (Table 1). The compensation irradiance $\left(E_{\mathrm{c} i}\right.$ Table 1) was not significantly affected by light or by temperature changes ( $p>0.05)$, reaching a mean of $26( \pm 5.5 \mathrm{SD}) \mu \mathrm{mol}$ photons $\mathrm{m}^{-2} \mathrm{~s}^{-1}$. This indicated that in lowlight cultures $\left(10 \mu \mathrm{mol}\right.$ photons $\left.\mathrm{m}^{-2} \mathrm{~s}^{-1}\right)$, no positive net photosynthetic growth could occur. This is confirmed by calculating the net photosynthesis at $E_{\mathrm{g}}$ (net $P_{\mathrm{i}}$ Fig. 6) with positive values above approximately $26 \mu \mathrm{mol}$ photons $\mathrm{m}^{-2} \mathrm{~s}^{-1}$.

\section{DISCUSSION}

It has often been shown that in sea ice communities where irradiance is low, microalgal inhabitants are remarkably shade adapted (e.g. Cota 1985, Palmisano et al. 1985, Robinson et al. 1995). The energy limitation in such environments may be partially offset by an increase in the amounts of photosynthetic pigments, and thus, in an increase in light-capturing ability per cell, as is commonly observed in ice algae (Antia et al. 1969, Reynolds 1984). In fact, the chl a content of Rhodomonas salina cells growing at $10 \mu \mathrm{mol}$ photons $\mathrm{m}^{-2} \mathrm{~s}^{-1}$ was 2 to 3 times as high as that of cells growing at $150 \mu \mathrm{mol}$ photons $\mathrm{m}^{-2} \mathrm{~s}^{-1}$. However, this difference was reduced for low-temperature cultures (Fig. 3) and was even smaller if chl a was expressed on a cell volume basis because of the decrease in biovolume per cell with increasing irradiance and temperature (Fig. 2).

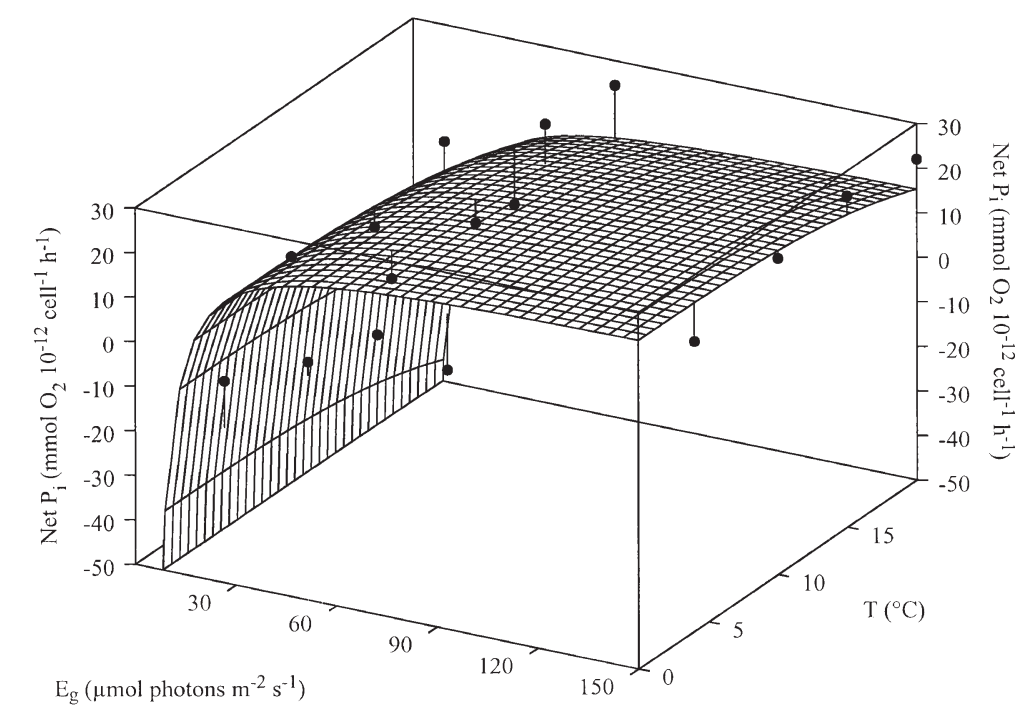

Fig. 6. Rhodomonas salina. Net photosynthesis $\left(P_{\mathrm{i}}\right)$ per cell versus growth irradiance $\left(E_{\mathrm{g}}\right)$ and temperature $(T)$ relationship. Fitted by the equation $z=30.04+0.12 x-491.92 / y, z=30.35-548.36 / x-0.34 y, \mathrm{r}^{2}=0.86, \mathrm{SE}=$ 8.94, $F=40.78$. Error bars $= \pm \mathrm{SD}$ 
Compared to other cryptophytes, which acclimate by changing their relative chl a content by a factor of 5 or more (Morgan \& Kalff 1979, Ojala 1993b), this was a rather limited increase.

Besides chl $a$, the photosystem II of cryptophytes receives excitation energy through the phycobiliprotein light-harvesting complex ( $\mathrm{LHC}_{\text {; }}$ MacColl et al. 1976, reviewed in Larkum \& Barrett 1983). By increasing the amount of LHC pigments by more than the cellular chl a content, this light-harvesting system allows photosynthesis to function with high efficiency under limited irradiance. This acclimation, i.e. the increase of the phycobiliprotein/chl a ratio at low irradiance, as shown for Cyanophyceae (Halldal 1958) or Cryptophyceae (Faust \& Gantt 1973), did not occur in our experiments. The PE/chl a ratio of Rhodomonas salina was constant for all light intensities within temperature regimes (Fig. 4), indicating a reduction in the number of all photosynthetic units per cell with increasing irradiances (Bernard et al. 1996). An inhibitory effect of nitrogen deficiency on PE production and phycobiliprotein degradation (Lichtlé 1979, Rhiel et al. 1985) can be excluded because we used a nitrogen-enriched medium and inocula from exponentially growing (i.e. nitrogen-sufficient) cultures. Furthermore, constant C:N ratios of $4.1( \pm 0.52$, not shown) were measured for the entire experimental set.

Phycobiliproteins were selectively reduced with decreasing temperature, which resulted in a significantly lower PE/chl a ratio ( $<<0.001$; Fig. 4). This reflects a strong decline in antennae size decreasing the amount of light energy absorbed and transferred to the reaction centres (Richardson et al. 1983, Raven \& Geider 1988). Low temperatures therefore seem to limit the ability or need to invest biosynthetic energy in light-harvesting pigments, leading to a pigmentation signature similar to that of high-light acclimated cells.

Low-light acclimation typically results in a decrease of the light saturation point $E_{\mathrm{k}}$, which can be caused either by a decrease in $P_{\max }$ (Falkowski 1980, Richardson et al. 1983), by an increase in $\alpha$ or by a combination of both. In our laboratory experiments, the very low light intensities to which Rhodomonas salina cultures were exposed did not depress $E_{\mathrm{k}}$ below the level obtained for high-light cultures (Table 1). Values were higher than in comparable field studies and never reached values below $10 \mu \mathrm{mol}$ photons $\mathrm{m}^{-2} \mathrm{~s}^{-1}$ (Table 1), as frequently recorded for low-light adapted algae and/or sea ice communities (reviewed in Cota \& Smith 1991, Thinh 1993, Robinson et al. 1995). The comparison between $E_{\mathrm{k}}$ and growth irradiance leads to the conclusion that available light was limited for cultures growing at irradiances $<60 \mu \mathrm{mol}$ photons $\mathrm{m}^{-2} \mathrm{~s}^{-1}$ and, in all cases, for the $10 \mu \mathrm{mol}$ photons $\mathrm{m}^{-2} \mathrm{~s}^{-1}$ cultures (Fig. 5). It did not show any significant variation over the entire range of growth irradiances at any temperature regime ( $p$ 0.05). Thus, if the change in $E_{\mathrm{k}}$ is the result of photoadaptation of algae to changing growth irradiance (Talling 1957, Henley 1993, Falkowski \& Raven 1997), then $R$. salina did not photoadapt to the very low light intensities (maximum $10 \mu \mathrm{mol}$ $\mathrm{m}^{-2} \mathrm{~s}^{-1}$ at noon, Schubert et al. 2001) observed under snow-covered ice in the DZBC. Nevertheless, $R$. salina is a relatively low-light adapted species with an average $E_{\mathrm{k}}$ value of $49 \mu \mathrm{mol} \mathrm{m} \mathrm{m}^{-2} \mathrm{~s}^{-1}$.

In contrast, $E_{\mathrm{k}}$ varied with temperature. With temperature increasing over the ambient range of 5 to $20^{\circ} \mathrm{C}, P_{\max }$ is enhanced at saturating irradiances, albeit significantly only in the range of 15 to $20^{\circ} \mathrm{C}$ ( $\mathrm{p}<0.05$, Tukey's test; Table 1). Previous studies have also reported an increase of $P_{\max }$ with temperature for a wide range of environments and algal species (e.g. Li et al. 1984, Priscu \& Goldman 1984, Tilzer et al. 1986). The photosynthetic efficiency, $\alpha$, appeared to be more temperature-dependent than $P_{\max }$, reaching a clear maximum at moderate temperatures of $15^{\circ} \mathrm{C}$ (Table 1). This implies minimum $E_{\mathrm{k}}$ values at this temperature and thus, our conjecture of best acclimation at this temperature. The increase of $E_{\mathrm{k}}$ with increasing temperature, which has often been described (Collins \& Boylen 1982, Palmisano et al. 1987, Henley 1992), was found in our study only in the range of 15 to $20^{\circ} \mathrm{C}$ (Table 1). Furthermore, $E_{\mathrm{k}}$ seems to be controlled by variations in $\alpha$ rather than in $P_{\max }$ (Beardall \& Morris 1976, Henley 1993).

With low-light-acclimation being virtually absent in Rhodomonas salina, reduced respiratory losses should be considered as an alternative cause for the existence of under-ice populations (e.g. Morgan \& Kalff 1979). For $R$. salina, in fact, respiration per chl a was reduced by about $1 / 2$ with decreasing light and temperature level (Table 1). Nevertheless, this reduction was insufficient to allow positive net photosynthesis $\mathrm{P}_{\mathrm{i}}$ at light intensities below $26 \mu \mathrm{mol}$ photons $\mathrm{m}^{-2} \mathrm{~s}^{-1}( \pm 5.5$; Fig. 6 ). It is possible that changes in the photosynthetic/respiration data might be partially attributed to a downward signal drift in the $\mathrm{O}_{2}$ electrode, which would systematically increase apparent respiration and decrease net photosynthesis. As pointed out by Falkowski et al. (1985), small differences in the experimental light field could lead to large differences in the measurements of gross photosynthesis, particularly at subsaturating levels. However, one advantage of the photosynthetic light dispensation system over the microelectrode method is the precise control of environmental conditions such as irradiance and temperature as well as the supply of reproducible and rapid measurements of $P-E$ curves (Wolfstein \& Hartig 1998). We therefore believe our results to be accurate, implying that the compensation point for algal photosynthesis $\left(E_{\mathrm{c}}\right)$ was at a rela- 
tively low and more or less constant light level (26 $\mu \mathrm{mol}$ photons $\mathrm{m}^{-2} \mathrm{~s}^{-1} \pm 5.5$ ), but nevertheless above the lowest irradiance examined $\left(10 \mu \mathrm{mol}\right.$ photons $\mathrm{m}^{-2}$ $\mathrm{s}^{-1}$ ). Thus, a reduced respiration rate might at best allow a long survival of $R$. salina under subcompensatory light intensities and suboptimal temperatures. However, it could not explain the observed significant growth at $10 \mu \mathrm{mol}$ photons $\mathrm{m}^{-2} \mathrm{~s}^{-1}$ for all temperature regimes (Fig. 1). As opposed to Cloern (1977) and Ojala (1993a), who pointed out that, in general, the growth rate of cryptophytes increases exponentially with temperature and irradiance, we observed a rather flat response to light changes. Growth rate changes in biovolume could be omitted as the cell volume of $R$. salina showed insignificant variations in irradiance (Fig. 2). According to various authors (e.g. Morgan \& Kalff 1979, Lewitus \& Caron 1990), however, a reduction in irradiance often gives rise to a decrease in carbon quotas and cell volume. Thompson et al. (1991) pointed out that species in which carbon quota and/or cell volumes increase at low irradiance (e.g. Sakshaug \& Andresen 1986) respond to a low energy environment in a way which is markedly different from species reducing the cell carbon at low irradiance. Judging from our results, $R$. salina also seems to pursue a different strategy to respond to low-light environments.

Changes with temperature in growth as well as in biovolume were comparable to literature data. For the low temperature culture $\left(5\right.$ and $\left.10^{\circ} \mathrm{C}\right)$, a significant negative correlation could be found between growth rate and biovolume (Spearman $\mathrm{r}=-0.93, \mathrm{p}<0.001$ ). Likewise, Morgan \& Kalff (1975) have shown that low temperature adversely affects cell division of cryptophytes more than photosynthesis, resulting in accumulation of carbohydrate and increase in cell volume. Overall growth rates of Rhodomonas salina were small similar to those for various cryptophytes (e.g. Cloern 1977). The experimental irradiances for maximum growth of $R$. salina $\left(E_{\mathrm{g}}=60 \mu \mathrm{mol}\right.$ photons $\mathrm{m}^{-2} \mathrm{~s}^{-1}=$ $2.59 \mathrm{~mol} \mathrm{~m}^{-2} \mathrm{~d}^{-1}$ for the experimental $12: 12 \mathrm{~h}$ cycle) corresponded to the field irradiance for maximum cryptophyte occurrence in the DZBC $\left(2.81 \mathrm{~mol} \mathrm{~m}^{-2} \mathrm{~d}^{-1}\right.$, Wasmund 1994). The discrepancy in maximum growth temperature between laboratory $\left(20^{\circ} \mathrm{C}\right)$ and field $\left(2.1^{\circ} \mathrm{C}\right.$, Wasmund 1994$)$ is easily explained as follows. Cryptophyceae are intensively grazed by zooplankton (review in Stewart \& Wetzel 1986) and out-competed by faster growing species. According to Wasmund (1994), during mild winters their biomass in the DZBC remained low due to the competition with Chlorophyceae.

In summary, we observed that Rhodomonas salina exhibited an incomplete low-light acclimation in terms of pigmentation and acclimation of $E_{\mathrm{k}}$ and $E_{\mathrm{c}}$. With respect to temperature acclimation, a distinct optimum at $15^{\circ} \mathrm{C}$ was observed for $\alpha$ and $E_{\mathrm{k}}$. However, acclimation of these parameters is insufficient to explain the positive growth rates measured at low light/low temperature conditions. McKnight et al. (2000) have shown that the concentration and the quality of labile DOC can affect the heterotrophic growth of overwintering algae. We therefore hypothesised that DOC assimilation from the seawater based medium must have been the means by which $R$. salina captured energy under low-light conditions. Measurements revealed a significant DOC decline $(p=0.01, t$-test $)$ during the experiment from $13.9 \pm 2.9$ to $8.9 \pm 4.4 \mathrm{mg} \mathrm{C}$ $\mathrm{l}^{-1}$, varying with irradiance and temperature conditions (data not shown). Following recent research about osmotrophy (McKnight et al. 2000) and phagotrophy (Roberts \& Laybourn-Perry 1999) in overwintering cryptophytes, we will investigate these mechanisms as an explanation for cryptophyte dominance in the DZBC at low light/low temperature conditions (Hammer et al. unpubl.).

Acknowledgements. The authors are grateful to R. W. Sanders and 2 anonymous reviewers for comments on this manuscript. This research was financially supported by a doctoral fellowship from the Deutsche Forschungsgemeinschaft and from the FAZIT scholarship to A.H.

\section{LITERATURE CITED}

Antia NJ, Cheng JY, Taylor FJR (1969) The heterotrophic growth of a marine photosynthetic Cryptomonad (Chroomonas salina). Proc Int Seaweed Symp 6:17-29

Arrigo KR, Robinson DH, Sullivan CW (1993) Vertical profiles of the bio-optical and photophysiological properties of sea ice microalgae within the platelet layer of McMurdo Sound, Antarctica. J Phycol 98:173-185

Beardall J, Morris I (1976) The concept of light intensity adaptation in marine phytoplankton: some experiments with Phaeodactylum tricornutum. Mar Biol 37:377-387

Bernard C, Eitenne AL, Thomas JC (1996) Synthesis and binding of phycoerythrin and its associated linkers to the phycobilisome in Rhodella violaceae (Rhodophyta): compared effects of high light and translation inhibitors. J Phycol 32:265-271

Cloern JE (1977) Effects of light intensity and temperature on Cryptomonas ovata (Cryptophyceae) growth and nutrient uptake rates. J Phycol 13:389-395

Collins CD, Boylen CW (1982) Physiological responses of Anabaena variabilis (Cyanophyceae) to instantaneous exposure to various combinations of light intensity and temperature. J Phycol 18:206-211

Cota GF (1985) Photoadaptation of high Arctic ice algae. Nature 315:219-222

Cota GF, Smith REH (1991) Ecology of bottom ice algae. III. Comparative physiology. J Mar Syst 2:297-315

Falkowski PG (1980) Light-shade adaptation in marine phytoplankton. In: Falkowski PG (ed) Primary productivity in the sea. Plenum Press, New York, p 99-119

Falkowski PG, Raven JA (1997) Aquatic photosynthesis. Blackwell Scientific Publishers, Malden

Falkowski PG, Dubinsky Z, Wyman K (1985) Growth-irradi- 
ance relationships in phytoplankton. Limnol Oceanogr 30: 311-321

Faust MA, Gantt E (1973) Effect of light intensity and glycerol on the growth, pigment composition, and ultrastructure of Chroomonas sp. J Phycol 9:489-495

Felip M, Camarero L, Catalan J (1999) Temporal changes of microbial assemblages in the ice and snow cover of a high mountain lake. Limnol Oceanogr 44:973-987

Gasol JM, Garcia Cantizano J, Massana R, Guerrero R, Pedros Alio C (1993) Physiological ecology of a metalimnetic Cryptomonas population: relationship to light, sulfide and nutrients. J Plankton Res 15:255-275

Gervais F (1997) Light-dependent growth, dark survival, and glucose uptake by cryptophytes isolated from a freshwater chemocline. J Phycol 33:18-25

Giroldo D, Vieira AAH (1999) Assimilation and release of ${ }^{14} \mathrm{C}$ in a tropical strain of Cryptomonas obovata (Cryptophyceae) exposed to several irradiances. J Plankton Res 21:1911-1921

Halldal P (1958) Pigment formation and growth in blue-green algae in crossed gradients of light intensity and temperature. Physiol Plant 11:401-420

Haxo FT, Fork DC (1959) Photosynthetically active accessory pigments of cryptomonads. Nature 184:1051

Henley WJ (1992) Growth and photosynthesis of Ulva rotunda (Chlorophyta) as a function of temperature and square wave irradiance in indoor culture. J Phycol 28:625-634

Henley WJ (1993) Measurement and interpretation of photosynthetic light-response curves in algae in the context of photoinhibition and diel changes. J Phycol 29:729-739

Henley WJ, Ramus J (1989) Time course of physiological response of Ulva rotunda to growth irradiance transitions. Mar Ecol Prog Ser 54:171-177

Ikävalko J (1997) Further observations on flagellates within sea ice in northern Bothnian Bay, the Baltic Sea. Polar Biol 19:323-329

Klaveness D (1981) Rhodomonas lacustris (Pascher \& Ruttner) Javornicky (Cryptomonadida): ultrastructure of the vegetative cell. J Protozool 28:83-90

Klaveness D (1985) Classical and modern criteria for determining species of Cryptophyceae. Bull Plankton Soc Jpn 32:111-128

Klaveness D (1989) Biology and ecology of the Cryptophyceae: status and challenges. Biol Oceanogr 6:257-270

Larkum AWD, Barrett J (1983) Light-harvesting processes in algae. Adv Bot Res 10:1-219

Laybourn-Parry J, Ellis-Evans JC, Butler H (1996) Microbial dynamics during the summer ice-loss phase in maritime Antarctic lakes. J Plankton Res 18:495-511

Lewitus AJ, Caron DA (1990) Relative effects of nitrogen or phosphorus depletion and light intensity on the pigmentation, chemical composition, and volume of Pyrenomonas salina (Cryptophyceae). Mar Ecol Prog Ser 61:171-181

Li WKW, Smith JC, Platt T (1984) Temperature response of photosynthetic capacity and carboxylase activity in Arctic marine phytoplankton. Mar Ecol Prog Ser 17:237-243

Lichtlé C (1979) Effects of nitrogen deficiency and light of high intensity on Cryptomonas rufescens (Cryptophyceae). I. Cell and photosynthetic apparatus transformations and encystment. Protoplasma 101:283-299

MacColl R, Berns DS, Gibbons O (1976) Characterization of cryptomonad phycoerythrin and phycocyanin. Arch Biochem Biophys 177:265-275

Marra J, Boardman DC (1984) Late winter chl a distributions in the Weddell Sea. Mar Ecol Prog Ser 19:197-205

McKnight DM, Howes BL, Taylor CD, Goehringer DD (2000) Phytoplankton dynamics in a stably stratified Antarctic lake during winter darkness. J Phycol 36:852-861

Morgan KC, Kalff J (1975) The winter dark survival of an algal flagellate-Cryptomonas erosa (SKUJA). Verh Int Ver Theor Angew Limnol 19:2734-2740

Morgan KC, Kalff J (1979) Effect of light and temperature interactions on growth of Cryptomonas erosa (Cryptophyceae) chlorophyll, photosynthesis, planktonic alga. J Phycol 15:127-134

Nebaeus M (1984) Algal water-blooms under ice-cover. Verh Int Ver Limnol 22(2):719-724

Ojala A (1993a) Effects of temperature and irradiance on the growth of two freshwater photosynthetic cryptophytes. J Phycol 29:278-284

Ojala A (1993b) Effects of light and temperature on the cell size and some biochemical components in two freshwater cryptophytes. Nord J Bot 13:697-705

Palmisano AC, SooHoo JB, Sullivan CW (1985) Photosynthesis-irradiance relationships in sea ice microalgae from McMurdo Sound, Antarctica. J Phycol 21:341-346

Palmisano AC, SooHoo JB, Sullivan CW (1987) Effects of four environmental variables on photosynthesis-irradiance relationships in Antarctic sea-ice microalgae. Mar Biol 94: 299-306

Platt T, Gallegos CL, Harrison WG (1980) Photoinhibition of photosynthesis in natural assemblages of marine phytoplankton. J Mar Res 38:686-701

Porra RJ, Thompson WA, Kriedemann PE (1989) Determination of accurate extinction coefficients and simultaneaous equations for assaying chlorophylls a and b extracted with four different solvents: verification of the concentration of chlorophyll standards by atomic absorption spectroscopy. Biochim Biophys Acta 975:384-394

Post AF, Dubinsky Z, Wyman K, Falkowski PG (1984) Kinetics of light-intensity adaptation in a marine planktonic diatom. Mar Biol 83:231-238

Priscu JC, Goldman CR (1984) The effect of temperature on photosynthetic and respiratory electron transport system activity in the shallow and deep-living phytoplankton of a subalpine lake. Freshw Biol 14:143-155

Raven JA, Geider RJ (1988) Temperature and algal growth. New Phytol 110:441-461

Reynolds CS (1984) The ecology of freshwater phytoplankton. Cambridge University Press, Cambridge

Rhiel E, Moerschel E, Wehrmeyer W (1985) Correlation of pigment deprivation and ultrastructural organization of thylakoid membranes in Cryptomonas maculata following nutrient deficiency. Protoplasma 129:62-73

Richardson K, Beardall J, Raven JA (1983) Adaptation of unicellular algae to irradiance: an analysis of strategies. New Phytol 93:157-191

Roberts EC, Laybourn-Parry J (1999) Mixotrophic cryptophytes and their predators in the Dry Valley lakes of Antarctica. Freshw Biol 41:737-746

Robinson DH, Arrigo KR, Iturriaga R, Sullivan CW (1995) Microalgal light-harvesting in extreme low-light environments in McMurdo Sound, Antarctica. J Phycol 31:508-520

Rodhe W (1955) Productivity: can plankton production proceed during winter darkness in subarctic lakes? Verh Int Ver Limnol 12:117-122

Rott E (1988) Some aspects of the seasonal distribution of flagellates in mountain lakes. Hydrobiologia 161:159-170

Sakshaug E, Andresen K (1986) Effect of light regime upon growth rate and chemical composition of a clone of Skeletonema costatum from the Trondheimsfjord, Norway. J Plankton Res 8:619-637

Sakshaug E, Holm-Hansen O (1986) Photoadaptation in Antarctic phytoplankton: variations in growth rate, chem- 
ical composition and P versus I curves. J Plankton Res 8: $459-473$

Salonen K, Jokinen S (1988) Flagellate grazing on bacteria in a small dystrophic lake. Hydrobiologia 161:203-209

Sanders RW, Porter KG, Bennett SJ, DeBiase AE (1989) Seasonal patterns of bacterivory by flagellates, ciliates, rotifers, and cladocerans in a freshwater planktonic community. Limnol Oceanogr 34:673-687

Santore UJ (1977) Scanning electron microscopy and comparative micromorphology of the periplast of Hemiselmis rufescens, Choomonas sp., Chroomonas salina and members of the genus Cryptomonas (Cryptophyceae). Br Phycol J 12:255-270

Schiewer U (1997) Design, experiences and selected results of meso- and microcosm experiments in shallow coastal waters 1981/95. Rostock Meeresbiol Beitr 5:37-51

Schubert H, Sagert S, Forster RM (2001) Evaluation of the different levels of variability in the underwater light field of a shallow estuary. Helgoland Mar Res 55:12-22

Sciandra A, Lazzara L, Claustre H, Babin M (2000) Responses of growth rate, pigment composition and optical properties of Cryptomonas sp. to light and nitrogen stresses. Mar Ecol Prog Ser 201:107-120

Stewart AJ, Wetzel RG (1986) Cryptophytes and other microflagellates as couplers in planktonic community dynamics. Arch Hydrobiol 106:1-19

Talling JF (1957) The phytoplankton population as a compound photosynthetic system. New Phytol 56:133-149

Thinh LV (1983) Effect of irradiance on the physiology and ultrastructure of the marine cryptomonad, Cryptomonas strain Lis (Cryptophyceae). Phycologia 22:7-11

Thinh LV (1988) Photoadaptation of photosynthesis in Cryp-

Editorial responsibility: Robert Sanders,

Philadelphia, Pennsylvania, USA tomonas strain Lis. Photosynthetica 22:405-410

Thompson PA, Harrison PJ, Parslow JS (1991) Influence of irradiance on cell volume and carbon quota for ten species of marine phytoplankton. J Phycol 27:351-360

Tilzer MM, Elbrächter M, Gieskes WW, Beese B (1986) Lighttemperature interactions in the control of photosynthesis in Antarctic phytoplankton. Polar Biol 5:105-111

Tranvik LJ, Porter KG, Sieburth JM (1989) Occurrence of bacterivory in Cryptomonas, a common freshwater phytoplankter. Oecologia 78:473-476

Vincent WF (1981) Production strategies in Antarctic inland waters: phytoplankton eco-physiology in a permanently ice-covered lake. Ecology 62:1215-1224

Walsby AE (1997) Numerical integration of phytoplankton photosynthesis through time and depth in a water column. New Phytol 136:189-209

Wasmund N (1994) Phytoplankton periodicity in a eutrophic coastal water of the Baltic Sea. Int Rev Gesamt Hydrobiol 79:259-285

Webb WL, Newton M, Starr D (1974) Carbon dioxide exchange of Alnus ruba: a mathematical model. Oecologia 17:281-291

Wiedner C, Nixdorf B (1998) Success of chrysophytes, cryptophytes and dinoflagellates over blue-greens (cyanobacteria) during an extreme winter (1995/96) in eutrophic shallow lakes. Hydrobiologia 369/370:229-235

Wolfstein K, Hartig P (1998) The photosynthetic light dispensation system: application to microphytobenthic primary production measurements. Mar Ecol Prog Ser 166: 63-71

Wright RT (1964) Dynamics of a phytoplankton community in an ice-covered lake. Limnol Oceanogr 9:163-178

Submitted: November 20, 2001; Accepted: May 26, 2002

Proofs received from author(s): September 6, 2002 